\section{Intersections}

Canadian Journal of Music

Revue canadienne de musique
Intersections CANADIAN JOURAL OF MUSIO

\title{
Music, Drinking and Dance at Aristocratic Russian Weddings under Peter the First as Witnessed by Friedrich Wilhelm von Bergholz
}

\section{Elizabeth Sander}

Volume 26, numéro 1, 2005

URI : https://id.erudit.org/iderudit/1013242ar

DOI : https://doi.org/10.7202/1013242ar

Aller au sommaire du numéro

Éditeur(s)

Canadian University Music Society / Société de musique des universités canadiennes

ISSN

1911-0146 (imprimé)

1918-512X (numérique)

Découvrir la revue

Citer cet article

Sander, E. (2005). Music, Drinking and Dance at Aristocratic Russian Weddings under Peter the First as Witnessed by Friedrich Wilhelm von Bergholz. Intersections, 26(1), 34-61. https://doi.org/10.7202/1013242ar
Résumé de l'article

Nous étudions dans cet article la danse et les rituels collatéraux tels qu'ils ont été pratiqués lors de cérémonies de mariages aristocratiques en Russie à la fin du règne de Pierre $1^{\mathrm{er}}$ (dit « le Grand ", 1672-1725). La principale source utilisée pour cette recherche est un journal écrit par le noble Holstein Friedrich Wilhelm von Bergholz (1699-1765) entre 1721 and 1725 lors de son séjour en Russie. Les danses utilisées à l'occasion de ces cérémonies répondaient naturellement à un plan formel consistant en révérences, cérémonial de danses et danses libres. Les menuets, ainsi que d'autres danses identifiées comme Polonaise et Anglaise, étaient également en faveur.
Copyright (C Canadian University Music Society / Société de musique des universités canadiennes, 2006
Ce document est protégé par la loi sur le droit d'auteur. L'utilisation des services d'Érudit (y compris la reproduction) est assujettie à sa politique d'utilisation que vous pouvez consulter en ligne.

https://apropos.erudit.org/fr/usagers/politique-dutilisation/ 
Music, Drinking and Dance at Aristocratic Russian Weddings under Peter the First as Witnessed by

\author{
FRIEDRICH WILHELM VON BERGHOLZ ${ }^{1}$
}

\title{
Elizabeth Sander
}

\section{INTRODUCTION}

One of the hallmarks of Russian society under Tsar Peter the First's reign was a penchant for long, lively and often drunken parties. Virtually any excuse would do, but few occasions lent themselves as easily to extensive festivity as did the wedding ceremony. In the course of his Tagebuch, Kammerjunker Friedrich Wilhelm von Bergholz (1699-1765) describes a number of wedding ceremonies he observed in Russia between 1721 and 1725. Some of these were held among the foreign residents of Moscow and St. Petersburg, but most of them took place among noble Russians. There were typically two to three consecutive days devoted to the celebration, and besides the actual marriage sacrament performed in church, festivities would include ceremonial processions, organized role-playing, magnificent feasting, ritualized drinking and extended jubilation through dance.

The most ambitious documentation of Russian wedding procedure found in Bergholz's diary is found in entries for two weddings held in the autumn of 1721. The first of these, held on 29 and 30 September, was for the marriage of the "young" Count Pushkin ${ }^{2}$ to a woman with the surname "Labanoffen," (Bergholz $1721 / 1785,132-6)$ and the second, held on 1 November, was for the marriage of "the young Prince Repnin" to a daughter of the "old" Pushkin (Bergholz $1721 / 1785,151-8)$. Both were lavish affairs involving, among other things, a great deal of dancing. Bergholz was to attend many more wedding ceremonies while in Russia, but with the exception of Duke Karl Friedrich of Holstein's marriage to Princess Anna Petrovna in May 1725, he tended to record only those details which struck him as significantly different from those he had already documented.

1 This text comprises one chapter from the author's forthcoming book Social Dancing in Peter the Great's Russia: Friedrich Wilhelm von Bergholz's Diary (1721-1725) to be published by Olms in the Terpsichore - Tanzhistorische Studien series, ed. Walter Salmen. All translations are the author's unless otherwise noted.

2 Bergholz spells the name "Puskin." 


\section{Officials, Processions, Drinking and Fanfares}

Before turning to a detailed examination of the dancing that took place, let us first consider some of the other significant features of the Russian wedding celebrations observed by Bergholz. One of the most invariable and predictable traditions was that of formalized role-playing. In advance of the wedding, people would be appointed to act as proxy relatives and wedding officials during the celebrations. Among other things, the people acting in these positions would participate in the ceremonial dancing that took place after the wedding banquet on the first day of wedding celebrations. Bergholz reports that at Prince Repnin's wedding, there was one Marschall (marshal), one Vorschneider ("carver"), twelve Schaffer ("stewards") and two Brautjungfer (bridesmaids), as well as a father of the bride, father of the groom, mother of the bride, mother of the groom, brother of the bride, brother of the groom, sister of the bride and sister of the groom (Bergholz 1721/1785, 152-3). With the exception of the royal wedding between Duke Karl Friedrich and Princess Anna Petrovna in 1725, this assortment of roles was absolutely standard at the Russian weddings recorded in Bergholz's diary. ${ }^{3}$ The only rules concerning the allotment of roles seem to have been that candidates had to be married and that they could not be actual relatives of the newlyweds. The Tsar and Tsaritsa were central participants in this custom, often acting as surrogate parents of the newlyweds. ${ }^{4}$ In fact, in the one instance when the imperial couple was absent from a Russian wedding attended by the Holsteiners, Bergholz expresses a sense of shock (Bergholz 1724/1788, 481).

The concept of appointing people to ritualistic wedding positions was, apparently, neither new nor unique to the era of Peter the Great. A similar practice had been described in Russia at least a century before Bergholz's diary was written, in a manual of domestic life called Domostroi, and there were apparently related customs in German-speaking lands up to three-quarters of a century later. Domostroi, which can loosely be translated as "Household Management," has survived in forty-three handwritten copies, the earliest of which probably dates back to the 1550s, from the reign of Ivan IV ("the Terrible"). The sections on wedding rituals were relatively late additions to the work, possibly dating from as late as the first quarter of the seventeenth century (Pouncy 1994, 4 and 38-40; Kaiser 1987, 250, FN 13).

One aspect of the fanciful reordering of social hierarchy at wedding rituals described in Domostroi was the treatment of the bride and groom, regardless of

3 There were twenty-four Schaffer but no wedding "relatives" at the royal wedding. Bergholz 1725/1788, 533-7 (21 May).

4 Bergholz 1721, 133 (the Tsar was the "groom's father" and Grand Chancellor Goloskin's wife substituted for the Tsaritsa as the "bride's mother"); Bergholz 1721/1785, 152-3 (the Tsar was the "groom's father" and the Tsaritsa was the "bride's mother"); Bergholz 1721/1785, 168 (the Tsar was the "groom's father" and the Tsaritsa was the "bride's mother"); Bergholz 1721/1785, 173 (the Tsar was the "groom's father" and the Tsaritsa was the "bride's mother"); Bergholz 1722/1786, 458-61 (the Tsar was Marschall and the Tsaritsa was the "bride's mother"); Bergholz 1722/1786, 470-1 (the Tsar was the "groom's father" and the Tsaritsa was the "bride's mother"); Bergholz 1722/1786, 235 (wedding of Germans, but the Tsar was still the "groom's father" and the Tsaritsa was the "bride's mother"); Bergholz 1723/1787, 346-7 (the Tsar and Tsaritsa were present and played noteworthy, but unspecified, roles); Bergholz 1724/1788, 477 (the Tsar and Tsaritsa were present and played noteworthy, but unspecified, roles). 
actual rank, as temporary prince and princess. Simulated royalty required simulated suites of royal attendants. The day before the wedding day, the groom and the bride's father were to inform each other about whom they had chosen to fill the necessary positions for each of their royal retinues. The groom, for his part, was to appoint people to the positions of proxy father and mother, ${ }^{5}$ master of ceremonies (tysiatskii, or thousandsman), members of the wedding procession, best man (druzhka, or friend) and matron of honour (svakha, or matchmaker). The bride's father would, on behalf of his daughter, appoint a best man and a matron of honour. People would also be appointed to perform such duties as to help the groom dismount from his horse, to take care of garments, to tend to the horses and to prepare the bride for bed (Kolesov 1991, 141). Daniel H. Kaiser writes that the wedding customs of Domostroi are very closely reflected in the extant wedding rosters for four of Ivan IV's seven weddings that took place between 1547 and 1581 (Kaiser 1987, 256). According to Russell E. Martin, extant documentation shows that traditions such as the roster of honorific and ceremonial positions had been in place-for royal Russian weddings-, at least since the beginning of the sixteenth century (Martin 2004, 795).

But although the descriptions of weddings found in Bergholz's diary suggest that the general idea of appointing people to predetermined positions had remained intact since earlier times, the positions themselves seem to have been different in Petrine weddings. It is certainly possible to draw parallels between the master of ceremonies (tysiatskii) of previous times and the Marschall of Peter's era, between the two matchmakers (svakhi) and the two bridesmaids (Brautjunfer), as well perhaps as between the members of the processional train and the twelve Schaffer, but in place of the two best men (druzhki) there was now one Vorschneider. Moreover, the proxy relatives of previous times had consisted only of parents of the bride and groom but in Peter's era also included brothers and sisters of the bride and groom. As discussed later in the present chapter, Bergholz seems to have been told that the customs practised at Russian weddings had been borrowed from foreigners. The apparent ease with which Bergholz uses German terms to describe Russian wedding positions makes it seem probable that the traditions described in Bergholz's diary were in fact cross-cultural phenomena. The appearance of these terms for wedding officials in Johann Christoph Adelung's 1798 Dictionary of the High-German Dialect further confirms that similar wedding customs were known in German-speaking lands at least until the end of the eighteenth century.

Of the entries for the words Marschall, Schaffer and Vorschneider in Adelung's dictionary, two definitions include reference to official wedding positions. The fifth definition Adelung provides for the word Marschall is:

At public celebrations now occurring at court or among private persons, certain people are often chosen to be Marschälle for the duration of the celebration. These people lead the whole procession or special sections thereof

5 The original reads: "kto vo ottsovo mesto i v materino" [who \{would be\} in the father's place and in the mother's]. (Kolesov 1991, 141) 
and in general are concerned with the external routine and observation of propriety. As a sign of their rank, they often carry a staff that is called the Marschalls staff [Marschalls-Stab]. ${ }^{6}$

Whereas the militaristic position of Marschall is related to such supervisory concerns as the management of parades and maintenance of general order, the position of Schaffer-which Adelung says is equivalent to Schaffner (Adelung 1798, s.v. "Der Schaffer)-is related to domestic service in an aristocratic household. Adelung writes that, in large households of Upper Germany, the word Schaffner is used to denote Haushofmeister or Hofmeister. Further in the same entry, there is reference to Schaffner being a position at rural weddings.

... at farmers' weddings, the one who serves the table and attends to the guests also bears this name and is usually the closest relative [of the host]. ${ }^{7}$

Using the spelling Bergholz uses, Adelung goes on to describe a dance.

The Schaffertanz is the first dance in said place [at farmers' weddings], because it honours the Schaffer. ${ }^{8}$

As we will see later, the first dance at the Petrine wedding ceremony, always referred to by Bergholz as the first ceremonial dance, functioned to honour all the wedding officials. Perhaps the designation Schaffertanz referred to the dance's relative position (i.e., first) and participating dancers (i.e., Schaffer and maybe other wedding officials), rather than to a unique dance type, just as the ceremonial dances at the Petrine wedding ceremony seem to have been likewise defined.

Adelung's entry for the word Vorschneider does not give any indication of a wedding position. However, under the entry for the verb vorschneiden, there is one meaning that is easy to relate to a private ceremony: "to carve the food for the guests; or else, to carve the food and lay it before the guests." Adelung equates this word to the verb transchiren borrowed from the French tranchir (Adelung 1798, s.v. "Vorschneiden"). ${ }^{9}$ One of the two definitions given for Vorschneider shows that this word could be used to denote a certain domestic position among the aristocracy:

6 "Bei öffentlichen Feierlichkeiten, sie fallen nun am Hofe oder unter Privat-Personen vor, werden oft gewisse Personen so lange die Feierlichkeit dauert zu Marschällen erwählet, welche den ganzen Zug, oder auch besondere Abtheilungen desselben anführen, und überhaupt für die äußere Ordnung und Beobachtung des Wohlstandes sorgen. Zum Zeichen ihrer Würde führen sie oft einen Stab, welcher der Marschalls-Stab genannt wird, in der Hand." Adelung 1798, s.v. "Der Marschall.

7 "... da denn auf den Bauerhochzeiten auch derjenige diesen Nahmen führet, welcher den Tisch besorget und die Gäste bedienet, und gemeiniglich der nächste Verwandte ist." Adelung 1798, s.v. "Der Schaffner."

8 "Der Schaffertanz ist daselbst der erste Tanz, weil derselbe den Schaffern gebühret." Ibid.

9 “... die Speisen vorschneiden, sie für die Gäste zerschneiden, eigentlich wohl, sie für die Gäste zerschneiden und ihnen vorlegen, mit einem Französischen Kunstworte transchiren." 
... a person who carves and serves food; and at courts, is often a special of-

ficial who is required to do this. ${ }^{10}$

Imagining a ritual wedding position related to or based on this kind of domestic position is not difficult. On account of Bergholz's unqualified use of the word Vorschneider to denote a member of the Petrine wedding party, one might be justified in speculating that, perhaps earlier in the eighteenth century, such an association with weddings did indeed exist in some German-speaking areas.

In addition to the appearance in Adelung's dictionary of applicable definitions for the words Marschall, Schaffer and Vorschneider, there is also an entry for the word "Hochzeitsvater." The definition given for this word proves beyond a doubt that a common link exists between the Russian wedding ceremonies under study and at least certain wedding ceremonies in German-speaking lands. According to Adelung, a Hochzeitsvater (wedding father) is:

The father who oversees his child's or another person's wedding [celebration] on the day of the wedding; so also is such a person of the female sex named wedding mother [Hochzeitsmutter]. ${ }^{11}$

The ritual positions described in Bergholz's diary were clearly not unique to Russia.

On most occasions, Bergholz's descriptions of Russian weddings lack any mention of the religious rite of marriage. Presumably, the Duke of Holstein had been invited only to the secular celebrations occurring after the private religious ceremony, or else Bergholz's very thorough diary would surely have included more references to the latter. Holstein did, however, get invited a month in advance to the wedding ceremony in Moscow of the young Count Goloskin to the daughter of Fedor Iur'evich Romadanovskii, the reigning "Prince-Caesar." Bergholz records the Duke's having witnessed not only the two-day secular celebrations, but also the church-centred ritual which took place on 8 April 1722 (Bergholz 1722/1786, 458-65). Reflecting a custom described in the Domostroi (Pouncy 1994, 206-8), as well as in extant documents for four of the weddings of Ivan IV (between 1547 and 1581) and the second wedding of Mikhail Romanov in 1626 (Kaiser 1987, 257; Martin 2004, 808), there was a formal procession of the newlyweds and their retinue to and from the church. At nine oclock in the morning, the Duke arrived at the designated meeting place, the "Red Gate."12 Although the wedding Marschall was supposed to have been there early in order to greet all the guests as they arrived, the Holsteiners in this case had to wait for over two hours before that official finally did appear. However, since it was the Tsar himself who was acting as Marschall, nobody could complain. After eleven o'clock, the Tsar arrived, and he conducted a procession first to fetch the groom

10 “... eine Person, welche die Speisen vorschneidet, und an Höfen oft ein eigener Beamter, der dieses zu thun verbunden ist." Adelung 1798, s.v. "Vorschneider."

11 "... der Vater, welcher seinem Kinde oder einer andern Person die Hochzeit ausrichtet, am Tage der Hochzeit; so wie eine solche Person weiblichen Geschlechtes die Hochzeitsmutter genannt wird." Adelung 1798, s.v. "Der Hochzeitsvater.

12 The "Red Gate" had also been the designated meeting place for the recent masquerade (30 January-4 February 1722). See, for example, Bergholz 1722/1786, 381. 
from his house and bring him to the church, and then to fetch the bride from her house and bring her to church. These two processions, which included twelve Schaffer, various proxy relatives and other wedding officials, were led by a pair of trumpeters that played only during the bridal procession to the church. ${ }^{13}$

Bergholz's recollection of the marriage ceremony that day is filled with auditory impressions. The Tsar's musical establishment was apparently present; Bergholz describes how the priest's chanting was sometimes joined by the entire Imperial Chapel (Bergholz 1722/1786, 459). Bergholz was surprised that, throughout the liturgy, which included such traditional ceremonies as the crowning of the bride and groom, there was a lot of noise and laughter arising from both the groom and the guests. After the marriage was completed, a formal procession accompanied the bride and groom to the house where the secular ceremonies were to take place.

On 10 November 1723, the occasion of General Pavel Ivanovich Iaguzhinsky's second marriage, Bergholz witnessed a similar procession to and from the church where the marriage rite was to be performed. This time, the religious ceremony took place in the late afternoon and most guests waited in the house where the feast would take place while the wedding officials accompanied the bride and groom to and from the church (Bergholz 1723/1767, 346-7). Bergholz's descriptions of these two examples of the church-centred part of the wedding ceremony demonstrate that one important function of the wedding officials was to form the core of the processional trains.

The secular ceremonies of Petrine weddings consisted of a mixture of traditional customs and ad hoc procedures evidently invented and enforced by the Tsar. Among the traditional customs were the hanging of ornamental "heavens" above the seats of the bride and groom and the processional entrance of the bridesmaids and other wedding dignitaries into the dining hall. The first major event of the traditional secular celebrations was extravagant feasting. On the first wedding day, men and women would dine at separate tables. All the female "relatives" would sit at the bride's table, and all the male "relatives" would sit at the groom's table; however, the male Vorschneider would sit at the bridal table, between the two bridesmaids whom he first would kiss (Bergholz 1721/1785, 152). Bergholz noted that one of the distinctions of the second wedding day was the mixing of the sexes at the dining tables. Although this would presumably have symbolized the sexual consummation of marriage after the first day of celebrations, Bergholz notes that the inebriation and sickness following the obligatory drinking could prevent the actual consummation from taking place for days (Bergholz 1722/1786, 472).

The ritual consumption of alcoholic beverages was de rigueur at the Russian wedding ceremony under the reign of Peter. After dinner was finished, the Marschall (who also controlled the beginning of dinner through a blessing of the food) and the Schaffer would begin the ceremonial drinking. At least six toasts would be made, and for each toast, all guests were obliged to empty their cups or glasses of alcohol. An extra amount of alcohol would be poured

13 The church is, unfortunately, not identified in the Tagebuch. 
into the groom's drinking vessel to ensure his complete drunkenness (Bergholz $1721 / 1785,135)$. Once the obligatory toasts had been concluded, Peter would order additional toasts at his discretion. Even after the ceremonial drinking ended and after the tables and chairs had been taken away to make room for dancing, the consumption of alcoholic drinks would still continue. The dancing was both accompanied by and followed by enforced drinking (applying both to ladies and to gentlemen), and the severe drunkenness which ensued "cost many people," in the words of Bergholz, "a lot of bitter tears, followed by headaches and other inconveniences." 14

The alcoholic beverages mentioned in connection with weddings in Domostroi, around a century before Bergholz's diary was written, were mead, kvass, beer and wine (Pouncy 1994, 205, 213, 216, 229, 230, 231 and 232). Pouncy notes that red wine was usual at elite weddings (Pouncy 1994, 216). She may be right, but her translation of "vina krasnye" as "red wines" is not necessarily accurate. Not only is the meaning of the first word ambiguous (plural of "vino," referring either to wine or to grain alcohol), but also because the second word (plural of the adjective "krasnyi") may not have meant red. In a recent Russian edition of Domostroi, the old word "krasnye" is noted to be equivalent to the modern term "luchshie" [best] (Kolesov 1991, 140). Moreover, the terms "krasnoe vino" [red wine] and "beloe vino" [white wine] had been in use since 1423 and 1534, respectively (Pokhlebkin 1992, 101). Though the author of the passage in Domostroi may have had red wines in mind, "vina krasnye" probably meant something closer to the less specific "fine spirits."

There was no consistent terminology for "vodka" in eighteenth century Russia. The word had been used as early as in the sixteenth century, but it appears to have referred officially only to medicinal, water-diluted tinctures, and only unofficially to alcoholic drinks (Pokhlebkin 1992, 132-3). From the mid-seventeenth century, the locution khlebnoe vino (grain wine) was sometimes used to distinguish distilled vodka from grape wine and other alcoholic beverages, but in the administrative and legal documents pertaining to the state's vodka industry, only the word vino (wine) was used (Pokhlebkin 1992, 102). Other Russian terms for grain spirits widely used in the seventeenth and eighteenth centuries were those referring to the drink's property of burning, such as goriachee vino (high-temperature wine) or goriashchee vino (wine that can burn) (Pokhlebkin 1992, 105-6). These terms were equivalent to Branntwein, the contemporaneous German term for all spirits. Bergholz variously refers to the alcohol served at Russian weddings of the early 1720s as Wein, Brandtewein (e.g., 1721/1785, 174), ungarische[r] Wein (e.g., 1721/1785, 174) and rothe[r] und weiße[r] Wein (e.g., 1725/1788, 536). Since an eighteenth-century European would surely have been able to recognize grape wine, one can safely interpret Bergholz's references to Hungarian wine, red wine and white wine at face value. Bergholz's unqualified references to Wein may either have signified grape wine, or may have been used in place of the ambiguous Russian term vino, which surely would have been part

14 "Vielen hat dieser Rausch voraus bittre Thränen, und nachgehends Kopfschmerzen und andre Ungelegenheiten gekostet." (Bergholz 1721/1785, 156) 
of Bergholz's Russian vocabulary. His references to Brandtewein, however, most definitely signified Russian grain wine, or vodka. ${ }^{15}$

Until the middle of the nineteenth century, Russian vodka was based almost exclusively on rye. Oats, wheat, barley and buckwheat were also used in small quantities during the distillation process. According to William Pokhlebkin, this grain-based Russian vodka was greatly superior to potato vodka.

Russian rye vodka does not induce such after-effects as a heavy hangover, and does not create aggressive moods in the drinker in the same way as potato or, worse still, sugar-beet vodka. (Pokhlebkin 1992, 149)

This may explain in part how organized activities requiring a fair degree of physical coordination, such as dancing, could take place at all at Petrine wedding ceremonies despite the heavy consumption of alcoholic drinks. Nevertheless, there were occasions when Peter the Great took extra measures to ensure drunkenness in the extreme. Bergholz mentions a "usual local custom" of mixing "bad wine" with "the most abominable grain brandy" for the sake of increasing intoxication (Bergholz 1721/1785, 157). As a result of one of the Tsar's outrageous whims, this practice was put into play at Prince Repnin's wedding. On 1 November 1721, Peter ordered all the ladies to make up for not having been able to comply fully with the forced drinking at a masquerade celebration three days earlier. ${ }^{16}$ At the wedding, after the dancing was over, the Tsar showed no mercy to anybody. One German lady who had unsuccessfully pleaded beforehand for exemption from the drinking order had a miscarriage the following morning (Bergholz 1721/1785, 157).

Music played an important role at Petrine wedding celebrations. Although Bergholz wrote frustratingly little about the musical accompaniment to dancing, he does provide us with several examples of the sounding of trumpets used for other purposes. As we have already seen, trumpeters provided the musical accompaniment to the formal processions to the church where the rite of marriage took place. In fact, processions from the church to the site of the secular celebrations were also sometimes accompanied by trumpet-playing. At Prince Trubetskoi's wedding, Bergholz observed that the return procession to the wedding house was accompanied by the sound of both trumpets and drums $(1721 / 1785,166) .{ }^{17}$ The formal processions to and from church at the Duke of Holstein's wedding in 1725 were exceptionally lavish. One drummer and four trumpeters (marching in pairs) provided the processional music, and the Holstein court musicians (Hofmusici) marched together with the Duke's other servants (Bergholz 1725/1768, 533-4). One might suppose that, if the Hofmusici did not play during the processions on that day, they very well may have provided some kind of divertissement during the feast.

The arrival of high-ranking guests at the wedding house seems always to have been announced by the sounding of trumpets. For example, when the Duke of

15 For more on the production and distribution of vodka in the seventeenth and eighteenth centuries, see Semenova 1982, 259-74.

16 This evasion of forced drinking is described in Bergholz 1721/1785, 151.

17 The bride was, according to Bergholz, Ivan Mikhailovich Golovin's favourite daughter. 
Holstein and his suite arrived at the wedding of "the young Count Pushkin" on 29 September 1721, there was a sounding of trumpets as the Marschall and the twelve Schaffer received him at his carriage (Bergholz 1721/1785, 132). Bergholz describes the same kind of greeting to the sound of trumpets at Prince Repnin's wedding on 1 November 1721 and on the second day of Prince Trubetskoi's wedding on 8 November 1721 (Bergholz 1721/1785, 151 and 167). Since Bergholz refers to both of these cases being "as usual," we can infer that the Duke's arrival at weddings was always greeted with the sound of trumpets. Sometimes the trumpet fanfares could be misconstrued. At a wedding taking place in the foreign community (though attended by high-ranking Russians), the Duke of Holstein rushed out of the dining hall upon hearing the sound of trumpets, thinking that this was a signal for the arrival of the royal princesses. In fact, to the merriment of the Tsaritsa, the fanfare was actually an announcement of the arrival of the bride and bridesmaids (Bergholz 1723/1787, 235).

Finally, trumpet fanfares were an integral part of the ceremonial drinking at the wedding feast. The toasts observed at Prince Repnin's wedding were in the following order: first to welcome everybody, then to honour the family of Ivan Mikhailovich (Peter's deceased co-Tsar), then to honour the bride and groom, then to honour the proxy mothers and fathers, then to honour the proxy sisters and brothers and, finally, to honour the Vorschneider and the two bridesmaids. Bergholz tells us that the sounding of trumpets both announced the beginning of the ceremonial drinking and followed each toasted person's spoken acknowledgment of the honour. This speech of gratitude could naturally only be given after every guest in the room had emptied his or her glass (Bergholz 1721/1785, 153).

Nikolai Findeizen speculates that the trumpet music played for all these royal announcements and other communicative purposes would have been analogous to the genre of the fanfare popular in contemporaneous Western Europe. ${ }^{18}$ One might also draw a link with earlier practices within Russia as described in Domostroi. According to that source, a fife, a tambourine and a trumpet were to announce the rising of the bride from bed on the second wedding day; tambourines were to mark the arrival of important men to the bathhouse where the groom was to be bathed that same morning; and the sounding of trumpets and tambourines was to mark the arrival of the wedding procession at the estate of the bride's parents later on the second wedding day (Pouncy 1994, 226 and 228).${ }^{19}$ However, the only reference in Domostroi to music accompanying a procession is made in relation to the bride singing songs and making obeisances as the wedding party travelled to church (Pouncy 1994, 238). In the description of a more elaborate wedding ceremony, the bride is said to sing wedding lamentations and weep bitterly just before the secular marriage rituals take place (Pouncy 1994, 217). These historic rituals may explain why in Bergholz's recollections, the trumpets sounded not for the groom's procession, but only for the

$18 \mathrm{He}$ refers to a collection of calls and fanfares for one and two trumpets found in the last part of the book Les Dons des enfans de Latone: La Musique et la chasse du Cerf, Poëmes dediés au Roy (Paris, 1734) (Findeizen 1928, 1:355-56).

19 The original Russian word used for tambourine is "nakrachi." (Kolesov 1991, 153 and 155) 
bride's procession to the church on 8 April 1722. Perhaps the trumpet music symbolically represented the songs.

\section{The Russian Wedding Ball}

When Peter deemed the ceremonial drinking to have finished, the Marschall would strike the ground with his staff and call out that it was time to rise. Bergholz notes that:

As soon as [the Marschall] announced the parra stavat [pora vstavat'], or get up, the dinner was removed, but prior to this, nobody is allowed to get up. $^{20}$

The hall or halls would then be cleared and prepared for dancing, and the dancing would fill the rest of the evening. The sequence of dances and types of dances followed a relatively formal and predictable pattern; for this reason, all the dancing will be referred to collectively as a "wedding ball" and the three discreet divisions that can be deduced from Bergholz's descriptions will be named as follows: the opening ceremonial dancing, the free dancing and the closing ceremonial dancing.

In 1928, Nikolai Findeizen wrote a few words about the ceremonial dancing at the Petrine wedding ceremony. Based perhaps on a passage from Bergholz's diary, Findeizen seems to conclude that there was one ceremonial dance, presumably defined by dance type. He writes:

At weddings, there was also a ceremonial dance during which the musicians, according to Bergholz, first played a kind of funeral march (that is, a piece in a slow $4 / 4$ tempo, in a minor mode) and in which the gentleman and lady of each pair successively made reverences; after which, a Polish was begun. ${ }^{21}$

A new interpretation of Bergholz's diary suggests something different. Before addressing this point further, let us consider Bergholz's concise overview of the ball held at the young Count Pushkin's wedding.

Now, after the tables had been taken out of the rooms, the dancing began with the following ceremonial dances. First of all, the Marschall with the bride, and the two oldest Schaffer with the bride's mother and bride's sister, all danced Polish, after they had first made a few figures with slow steps, making reverences to the company while dancing by, or more aptly put, while walking by. Then the Marschall danced a second time with the bride, still holding his staff in his left hand, and two different Schaffer danced with the groom's mother and groom's sister. Following this, the groom danced

20 "So bald aber selbiger das parra stavat, oder Aufstehen, ankündiget, wird die Mahlzeit aufgehoben, vorher aber darf niemand aufstehen" (Bergholz 1721/1785, 135. See also Bergholz 1721/1785, 153).

21 "Na svad'bakh prodelyvalsia eshche osobyi tseremonnal'nyi tanets, prichem muzykanty, po slovam Berkhgol'tsa, igrali snachala rod pogrebal'nogo marsha (t. e. p'esu medlennogo tempa v 4/4, $v$ minore), v prodolzhenie kotorogo kavaler i dama pervoi pary, a za nimi i ostal'nye delali reveransy; zatem nachinalsia pol'skii." (Findeizen 1928, I, 354) 
with the bride, the bride's father with the groom's mother and the bride's brother with the groom's sister. After this, the groom danced for a second time with the bride, the groom's father with the bride's mother, and the groom's brother with the bride's sister. Then the Vorschneider danced with each bridesmaid in turn, and two Schaffer danced with two young women; during these dances, the Marschall, holding his staff, always had to dance alone, in front of everybody. At this point, the ceremonial dances were over, and now everybody was free to dance. His Highness began by dancing a minuet with the bride. At around eleven o'clock, the last ceremonial dance took place, in which the Marschall again danced in front, followed by the bride and groom, all the other relatives, and various other married people, who, after first having made a few figures, danced ahead, together with the musicians and all the Schaffer, together with small, lit torches, to the bridal chamber, where they were served sweets. Usually, the groom receives his final summons at the table. No unmarried people follow [the dancers into the bridal chamber], so His Royal Highness also went home, since it was already late and he had become tired. ${ }^{22}$

This passage clearly distinguishes between "ceremonial" dances and free dances, and it also clearly shows that ceremonial dances occurred both at the beginning of the ball and at the end of the ball. Corresponding to Findeizen's remarks, the opening ceremonial dancing consisted of two distinct components, the first of which clearly functioned as a coordinated means of displaying the dancers, and the second of which is identified by Bergholz as "Polish." "Dancing Polish" occurred six times with the participation of eighteen, presumably predetermined, couples. As discussed below, the ceremonial dancing Bergholz calls "Polish" may have been a generic dance type rather than simply a style. The order and official roles of participants is summarized below. ${ }^{23}$

22 "Nachdem nun die Tische aus den Zimmern genommen worden, ging der Tanz an, und zwar mit folgenden Ceremonieltänzen. Zuerst tanzete der Marschall mit der Braut, und die zwei ältesten Schaffer mit Braut Mutter und Schwester, polnisch, nachdem sie vorher einige Touren mit langsamen Schritten gemacht, und die Gesellschaft im Vorbeitanzen oder vielmehr Gehen, ihre Reverenzen gemachet. Darauf tanzete der Marschall zum andernmal mit der Braut, immer seinen Marschallsstab in der linken Hand haltend, und zwei andere Schaffer mit des Bräutigams Mutter und Schwester. Alsdenn tanzete der Bräutigam mit der Braut, auch Braut Vater mit Bräutigams Mutter, und Braut Bruder mit Bräutigams Schwester. Nach diesem tanzete der Bräutigam zum zweitenmal mit der Braut, und Bräutigams Vater mit Braut Mutter, nebst Bräutigams Bruder mit der Braut Schwester; worauf denn der Vorschneider mit einer jeden Brautjungfer einmal tanzete, und zwei Schaffer mit zwei Fräulein; der Marschall aber mußte bei diesen Tänzen allemal mit dem Stab allein voran tanzen. Hiermit hatten die Ceremonieltänze ihr Ende, und nun hatte einjeder Freiheit zu tanzen, da denn Ihro Hoheit zuerst anfingen mit der Braut eine Menuet zu tanzen. Gegen 11 Uhr geschahe der letzte Ceremonieltanz, als wobei der Marschall wieder voran tanzete, nachdem Braut und Bräutigam, und so alle Verwandten, und verschiedene andere verheirathete Leute mehr, welche, nachdem sie einige Touren gemachet, mit der Musik, und sämmtlichen Schaffern, auch mit brennenden kleinen Wachsfackeln, voran nach der Brautkammer tanzeten, woselbst sie mit Confituren tractiret wurden. Gemeiniglich bekommt der Bräutigam daselbst am Tische seine letzte Ladung. Von unverheiratheten Leuten folget niemand dahin, daher sich Ihro königl. Hoheit auch nach Hause begaben, indem es schon spät war, und sie sich ermüdet hatten." (Bergholz 1721/1785, 135)

23 Only eight of the twelve Schaffer are accounted for in this schema. But it appears that all twelve only participated in the closing ceremonial dance. 


\begin{tabular}{|c|l|l|l|l|}
\hline $\begin{array}{c}\text { Dance } \\
\text { No. }\end{array}$ & \multicolumn{3}{|c|}{ Participating Dancers } \\
\hline & \multicolumn{2}{|c|}{ Leader } & \multicolumn{2}{c|}{ Couples } \\
\hline 1 & Marschall with Bride & $\begin{array}{l}\text { Schaffer \# 1/ } \\
\text { Bride's Mother }\end{array}$ & $\begin{array}{l}\text { Schaffer \# 2 / } \\
\text { Bride's Sister }\end{array}$ \\
\hline 2 & Marschall with Bride & $\begin{array}{l}\text { Schaffer \# 3 / } \\
\text { Groom's Mother }\end{array}$ & $\begin{array}{l}\text { Schaffer \# 4 / } \\
\text { Groom's Sister }\end{array}$ \\
\hline 3 & $\begin{array}{l}\text { Marschall } \\
\text { alone }\end{array}$ & Groom / Bride & $\begin{array}{l}\text { Bride's Father / } \\
\text { Groom's Mother }\end{array}$ & $\begin{array}{l}\text { Bride's Brother / } \\
\text { Groom's Sister }\end{array}$ \\
\hline 4 & $\begin{array}{l}\text { Marschall } \\
\text { alone }\end{array}$ & Groom / Bride & $\begin{array}{l}\text { Groom's Father / } \\
\text { Bride's Mother }\end{array}$ & $\begin{array}{l}\text { Groom's Brother / } \\
\text { Bride's Sister }\end{array}$ \\
\hline 5 & $\begin{array}{l}\text { Marschall } \\
\text { alone }\end{array}$ & $\begin{array}{l}\text { Vorschneider / } \\
\text { Bridesmaid \# 1 }\end{array}$ & $\begin{array}{l}\text { Schaffer \# 5 / } \\
\text { Young Woman \# 1 }\end{array}$ & $\begin{array}{l}\text { Schaffer \# 6 / } \\
\text { Young Woman \# 2 }\end{array}$ \\
\hline 6 & $\begin{array}{l}\text { Marschall } \\
\text { alone }\end{array}$ & $\begin{array}{l}\text { Vorschneider / } \\
\text { Bridesmaid \# 2 }\end{array}$ & $\begin{array}{l}\text { Schaffer \# 7 / } \\
\text { Young Woman \# 3 }\end{array}$ & $\begin{array}{l}\text { Schaffer \# 8 / } \\
\text { Young Woman \# 4 }\end{array}$ \\
\hline
\end{tabular}

In overall procedure, the opening ceremonial dancing held at Prince Repnin's wedding (1 November 1721) closely resembles the opening ceremonial dancing described above. The only discrepancies between the two accounts are that, in the latter case, the groom's mother and sister danced before the bride's mother and sister and the groom's brother and bride's sister danced before the bride's brother and groom's sister. For some reason, the bride's "relatives" seem to have been given precedence at Pushkin's wedding, whereas the groom's "relatives" were given precedence at Repnin's wedding. In his description of Repnin's wedding, Bergholz goes on to describe the nature of the dances in more detail; one point of interest is that dancing continued after the last ceremonial dance. The following passage is surely the original source of Findeizen's allusion to a "funeral march."

Now I must briefly convey what the dances were that were danced. Exactly as in English dances, the ladies stand on one side, and the men stand on the other side. The musicians first play a kind of death dance [Todtentanz], during which time the first couple, before joining [hands], make reverences to their neighbours and then to each other, at which point they join [hands] and make a circle to the left until returning to their previous position; and this can only be called walking, for they do not keep time, but make simple reverences to all the people standing around. The other two pairs immediately follow the first and copy everything. When everybody has finished making their circles, a Polish is played, to which they then dance in ordinary fashion. With this, it [the dancing] is finished. ${ }^{24}$

24 "Nun muß ich mit wenigen Worten melden, welche Tänze es sind, die sie getanzet haben. Die Damen stehen gleich als bei den engelschen Tänzen auf der einen, und die Mannsleute auf der anderen Seite. Die Musikanten spielen anfänglich eine Art von Todtentanz, während dieser Zeit macht das erste Paar, ehe es sich anfasset, Reverenzen an seine Nachbaren, und so gegen einander, worauf sie sich anfassen, und eine runde Tour links um machen, bis daß sie wieder auf ihre alte Stelle kommen, welches denn nur kann gespatziret heissen, indem sie keinen Tact halten, sondern an alle Herumstehende nur 
Findeizen's deduction that the first music must have been in common time and a minor key was perhaps based on an association made between Bergholz's word Todtentan $z$ and the "Trauermarsch" idiom of the later eighteenth to nineteenth centuries. Yet Findeizen's general inference that the effect was somewhat funereal was probably right. It is highly unlikely that the opening reverences at the Petrine wedding ball had anything to do with the lively Totentanz, or Dance of Death, musical genre; ${ }^{25}$ on the contrary, Bergholz's one-time use of the word Todtentanz should probably be understood in a personal, impressionistic sense, conveying the apparent sombreness of the music and lack of sprightliness among the dancers.

Supporting the theory concerning the funeral appearance of the dancers, one might consider Bergholz's specific references to the poor physical condition of the bride and groom during the dancing that followed these very reverences observed on 1 November 1721. He notes that there was a sharp contrast between the way in which the young newlyweds danced and the way in which the Tsar and Tsaritsa danced.

At this point, the groom danced for a second time with his bride, the Tsar as father with the Tsaritsa as mother, Prince Golitsyn as brother and $\mathrm{Ma}$ dame Balken as sister. It was a treat to watch this dance, for the groom did not really dance with his bride, but rather, they walked like a pair of old sleepy-heads and were actually dragging each other around. In contrast, the Tsar and the Tsaritsa were dancing and jumping about as the youngest people always like to do, for they made three turns in the time that the bride and groom could barely make one turn; and as much as the Tsaritsa was jumping this time, so slowly does she otherwise move when she dances with anybody else. ${ }^{26}$

Although Bergholz does not specifically attribute the newlyweds' stupor to alcoholic intoxication, such an explanation seems to be most obvious. Young Russian aristocrats, as these newlyweds were, would certainly have known how to dance at least as well as the Tsar; for what the Tsar demonstrated in vitality and tolerance of alcohol, he did not reportedly make up for in gracefulness. The humorous response to the newlyweds' tribulations on the dance floor seems consistent with the prescribed humorous response to the drunkenness prevalent during the entire wedding ceremony.

Having concluded that the introduction of the opening ceremonial dancing at the Russian wedding ball was not literally some kind of death-dance, we can

blosse Reverenzen machen. Die andern beiden Paare folgen dem ersten gleich, und machen ihm alles nach. Wenn nun alle diese Touren gemachet haben, so wird polnisch gespielet, wornach sie denn auch ordentlich tanzen, und es damit endigen." (Bergholz 1721/1785, 154-5)

25 For consideration of early examples of the genre, see Meyer-Baer 1970, 309-312.

26 "Hierauf tanzte der Bräutigam zum zweitenmal mit seiner Braut, der Kaiser als Vater mit der Kaiserin als Mutter, der Fürst Gallitzin als Bruder mit Madame Balken als Schwester. Es war eine wahre Lust, diesen Tanz anzusehen, denn der Bräutigam tanzte nicht mit seiner Braut, sondern sie gingen wie ein Paar alte Schlafmützen, und schleppten sich recht einander. Dagegen tanzete und sprang der Kaiser mit der Kaiserin herum, als die jüngsten Leute immer thun mögen, denn sie machten drei Wendungen, wenn die ersten kaum eine machten, und so wie die Kaiserin diesesmal sprang, so langsam gehet sie sonsten, wenn sie mit jemand anders tanzet." (Bergholz 1721/1785, 154) 
speculate on its nature from another perspective. One useful point of comparison is the ballroom procedure in roughly contemporaneous France, the central source of ballroom vogue in Europe at the time. In Le Maitre a Danser (1725), Pierre Rameau discusses the ceremonial procedures that had taken place at the King's Grand Ball under the reign of Louis XIV. This was "the most important of all such functions" and was to "serve as a model for private Balls in regard to the order of the proceedings, and the respect and politeness to be observed thereat" (Rameau 1725, 37). Rameau takes great pains to describe the display of social rank inherent in the opening parts of the ball.

The King takes up his position at that end of the room where the dancing is to begin, which is near the musicians. In the time of the late King [Louis XIV], the Queen danced with him, or, in her absence, the first Princess of the Blood, and placed themselves first. Then the company took up their station behind them, two by two, according to their rank. That is to say: Monseigneur [the King's eldest son] and Madame la Dauphine [the wife of the King's eldest son], Monsieur [the King's brother] and Madame [the wife of the King's brother], then the other Princes and Lords. The Lords stood on the left side, the Ladies on the right. Retaining this order, they made their bows in turn. Afterwards the King and Queen led the Branle with which all Court Balls opened, and all the Lords and Ladies followed Their Majesties, each on their own side. At the conclusion of the strain, the King and Queen went to the end of the line, then the next couple led the Branle in their turn, after which they took up their position behind Their Majesties. This continued until all the couples had danced and the King and Queen were at the head again. (Rameau 1725, 37-8)

The strict observance of social hierarchy described here by Rameau neatly corresponds in conception to the strict observance of make-believe social hierarchy observed during the ceremonial dancing of the Petrine wedding ball. Rameau's description clearly indicates that orderly reverences were made before the beginning of the first dance. Rameau does not indicate whether or not music was played during these reverences, but if it were, one could easily imagine the music being slow and ponderous, equivalent in spirit, perhaps, to what a contemporary observer may have found suitable for a funeral. Just as the opening reverences of the King's Grand Ball preceded the first, most formal, dance, so too did the opening reverences of the Petrine wedding precede the first ceremonial dance. In light of the apparent correspondence between the French and Russian customs, we will for now refer to the opening reverences of the Petrine wedding ball as the "formal reverences."

Whereas the formal reverences of the royal ball described by Rameau were immediately followed by the dancing of the branle, a group dance that highlighted one couple at a time according to rank, the formal reverences of the Petrine wedding ball were followed by what Bergholz identifies as a Polish dance, highlighting three couples at a time according to their ritual wedding roles. The organization of the opening ceremonial dancing at the Petrine wedding ball required several important people to dance more than once, and with more than one partner. It is unclear whether the formal reverences were executed only by 
the first three couples who participated in the Polish dancing, or whether each group of three couples executed it before the Polish dancing was begun. Bergholz implies that the double-row formation of the dancers was observed both during the formal reverences and during the ceremonial execution of the Polish dancing.

There is intuitive reason to suppose that Bergholz's locution "dancing Polish" [polnisch tanzen] signified some variant of the polonaise, rather than a general style. Before the mid-eighteenth century, the polonaise had been referred to in Poland not as polonez, but by various other names, such as taniec wielki [great dance]. ${ }^{27}$ However, the German designation Polnischer Tanz had been used to describe an early polonaise as far back as in the fifteenth century. Early manifestations of the polonaise as a folk dance had been associated with wedding celebrations. By the seventeenth century, the dance was also observed by foreigners at the Polish court, and by the mid-eighteenth century, there were theatrical instances. The following describes the polonaise in the second half of the eighteenth century.

A dignified dance in triple meter (3/4) in a moderate tempo, the polonez was often used to open balls. Led by the most distinguished couple present, it was a solemn processional that reaffirmed the importance of rank and provided an occasion for the display of splendid national robes. The male dancer led his female partner on his right side, her hand placed on his palm, which was outstretched in front of him. From time to time he passed the lady in front of him to his other side, then back again. The dance was varied by bows and polite conversation. (Cohen 1998, s.v. "Polonaise" by Susan $\mathrm{Au}$ )

There is some difficulty in comparing the details of this description to those provided by Bergholz. However, the overall effect of the dance described here appears to be the same. The opening ceremonial dance at the Russian wedding ball was indeed a processional affair; and, together with the arrangement of the outdoor processional trains and the seating plan for dinner, it was a primary vehicle through which wedding officials and proxy relatives were distinguished and displayed. The following passage, taken from a longer citation featured below, illustrates how Polish dancing at the Petrine wedding ball was processional and interspersed with reverences.

Afterwards, Kammerjunker Balk asked the Princess to dance, and he danced the Polish with her. The ladies stood up immediately when she began [to dance], and when she passed by the Empress and made a reverence, His Highness likewise stood up, and he remained standing until the dance was over. ${ }^{28}$

27 Information on the early polonaise is found in Cohen 1998, s.v. "Polonaise."

28 "Nachdem forderte der Kammerjunker Balk die Prinzeßin auf zum Tanz, und tanzte polnisch mit ihr; die Damen standen gleich auf, wie sie anfing, und da sie gegen der Kaiserin über kam, und einen Reverenz machte, stunden Ihro Hoheit gleichfalls auf, und blieben stehen, bis der Tanz zum Ende war." (Bergholz 1721/1785, 155-6) 
The foregoing description of the late eighteenth-century polonaise indicates that, in Poland, the dance was often used to open balls. In the case of Petrine wedding celebrations in Russia, the first ceremonial dance (after the formal reverences) was invariably Polish, and the closing ceremonial dance was also Polish. Moreover, "the Polish" was also a staple of the free dancing occurring between the opening and closing ceremonial dances. The particular instance cited in the quotation above occurred in the middle section of a wedding ball.

Unfortunately, there is insufficient evidence to make a definitive assessment of the relationship between early versions of the polonaise and what Bergholz refers to as "the Polish" or "dancing Polish." One might question who else, besides Bergholz, referred to the dances he observed in the same way. In Adelung's dictionary of 1798, there is no citation for polonaise, and the citation for the word "Polnisch" includes no reference to music or dance. However, one of the examples of usage given under the heading "Tanzen" does include the noun "Polonoise": "Einen Reihen, eine Minuet, eine Polonoise tanzen." Though he does use the word "Polnisch" variously as an adverb (polnisch tanzen, or auf polnisch tanzen) and as an adjective (den Polnischen Tanz tanzen), Bergholz never uses any variant of the term polonaise, so we cannot be certain to what extent Bergholz's references may have indicated form or manner. Nevertheless, a fair conjecture seems to be that "dancing Polish" at the Petrine wedding ball meant dancing some early variant of the polonaise.

The King's Grand Ball described by Rameau was roughly divided into two sections, where the opening reverences and two group dances (the branle and the gavotte) were followed by couple dances, or danses a deux. Rameau reports that, during the reign of Louis XIV, the couple dances would have been the courante, but that by the time of his writing, the courante had been replaced by the minuet (Rameau 1725,38 ). Correspondingly, there was also a clearly demarcated division following the opening ceremonial dances of the Petrine wedding ball. But in this case, the second portion of dancing was distinguished not by dance type, for the "Polish" dance could be found throughout the wedding ball, but by being open to all guests rather than restricted to just the wedding officials and proxy relatives. For example, this is how Bergholz describes the transition at Prince Repnin's wedding. Note how the first free dance was the Polish, presumably the same dance that had just been performed ceremonially.

When these six ceremonial [Polish] dances were finished, the Marschall struck the floor with his staff a few times, and he called out that now everybody was free to dance. After a little while, His Highness went to the Empress and took her up to dance, and she immediately showed herself willing to do so, and they began to dance Polish, together with Prince Menshikov, who had at the same time taken up Madame Balken. ${ }^{29}$

29 "Wie nun diese sechs cerimoniellen Tänze vorbei waren, klopfte der Marschall einigemal mit seinem Stock, und rief, jetzt hätte ein jeder die Freiheit zu tanzen; worauf eine Weile hernach Ihro Hoheit zu der Kaiserin gingen, und sie zum Tanz aufnahmen, welche sich denn alsobald sehr willig dazu zeigte, und mit ihnen anfing polnisch zu tanzen, nebst dem Fürsten Mentschikof, welcher selbigesmal Madame Balken aufgenommen hatte." (Bergholz 1721/1785, 155) 
This passage implies that only two couples danced at a time, but it is possible that freedom extended beyond who was allowed to dance and when, to how many couples could dance at a time.

Rameau's description of the danses a deux demonstrates that, at the King's Grand Ball, ladies and gentlemen took turns in receiving partners in dancing the minuet, in such a manner that each participant would dance twice. The same idea held true for any minuet performed during the free dancing of the Petrine wedding ball. However, the similarities between the French danses a deux and the Russian free dancing end there. Whereas there seems to have been a predetermined selection and ordering of dancers during the French danses a deux, the selection and ordering of dancers during the Russian free dancing seems in fact to have been free. Moreover, the dominance of the minuet (or courante) in the French case contrasts greatly with the seemingly spontaneous arrangement of dance types found at the Petrine wedding ball. The free dancing at the wedding of Prince Repnin, for example, which had begun with Polish dances, continued with minuets, English dances and more Polish dances.

Then Kammerjunker Balk danced a minuet with the eldest Fräulein Goloskin, who then took up His Highness. His Highness then took up the bride, who danced very stiffly, standing so straight that she appeared to be afraid of losing some of her jewellery. She wore a kind of tiara on her head and had many stones besides in her hair which made for a very good effect when light reflected in them, particularly since she was a brunette with a very white face. Her Majesty the Empress looked more magnificent than anyone else, especially her head on which she wore her complete royal jewellery. The Princess [Praskovia Ivanovna] had gone into the adjoining room, and the Empress asked His Highness to sit in that same seat [which the Princess had occupied], and she talked at length with His Highness. The Duke was taken up to dance several times, but as soon as he would finish a dance, the Empress would wave him over, and he would have to sit down next to her at once. ... The Emperor sat for the whole time near the entrance to the room so that he could also watch the dancing. He had all the important people sitting around him, however, he spoke most of the time with Field Marshal Bruce, who sat at his left side. While His Highness [the Duke of Holstein] danced a few English dances one after another, the daughter of the widowed Tsaritsa came and sat in her former place that His Highness had occupied in her absence near the Empress, but as soon as the English dance was over, the Empress called the Duke over to herself again, and the bride, who had been sitting under the "heaven" to the Empress's right, had to stand up to concede her place to His Highness. ... Afterwards, Kammerjunker Balk asked the Princess to dance, and he danced the Polish with her. The ladies stood up immediately when she began [to dance], and when she passed the Empress and made a reverence, His Highness likewise stood up, and he remained standing until the dance was over. ${ }^{30}$

30 "Nachdem tanzte der Kammerjunker Balk eine Menuet mit der ältesten Fräulein Golloskin, welche darauf Ihro Hoheit aufnahm, und Ihro Hoheit wieder die Braut, die nur sehr steif tanzet, allein es schien als wenn sie bange wäre, etwas von ihrem Schmuck zu verlieren, daher sie sich so gerade hielt. Sie hatte eine Art von Krone auf dem Kopf, und noch viele Steine in den Haaren stecken, welches denn 
In this case, there seem to have been three dance types: the minuet, as well as dances labelled by Bergholz as Polish and English.

The passage cited above does not provide much insight into the nature of the English dances in which the Duke of Holstein participated, but another passage, taken from Bergholz's description of wedding celebrations of eleven days later, shows that the English dance, at least in this latter case, was for a large group.

Upon these words [uttered by the Tsaritsa in conversation with Duke Karl Friedrich], General Iaguzhinskii came into the room. The Tsaritsa began an English dance with him that consisted of eight or nine couples and that was very long. The Tsaritsa and the Princess sat down to rest a little when it was not their turn to dance. ${ }^{31}$

The obvious deduction would be that what Bergholz calls English dances were English country dances, or contredanses (see Sander 2002, 95-96 and 109-115). Upon making such a statement, however, one must bear in mind the precautions already mentioned with regards to equating "Polish dances" to polonaises. The presence of certain similarities neither proves that Bergholz was referring to specific dance types, nor that he was referring to form rather than style. In fact, in one of his descriptions of weddings occurring in the foreign community, Bergholz draws an apparent distinction between English dances and contredanses.

For as long as the bride had been with us, we had not been able to dance English and Contratänze.... ${ }^{32}$

How dancing "English" related to the "Contratänze" mentioned by name is, for now, unclear.

eine sehr gute Wirkung bei Licht machte, insonderheit weil sie eine Brünette, und ziemlich weiß vom Gesicht war. Ihro Majestät die Kaiserin war über die Massen prächtig, insonderheit aber auf dem Kopf, auf welchem sie einen vollkommenen kaiserlichen Schmuck hatte. Die Prinzeßin war in das Nebenzimmer gegangen, daher bat die Kaiserin Ihro Hoheit, sich auf derselben Stelle zu setzen, und sprach sehr viel mit Ihro Hoheit. Der Herzog wurde unterschiedene male zum Tanz aufgenommen, so bald selbiger aber zum Ende war, winkte die Kaiserin ihm schon wieder, und er mußte sich gleich bei ihr niedersetzen. Der Kaiser saß die ganze Zeit nahe an der Stubenthür, doch so, daß er das Tanzen mit ansehen konnte. Er hatte alle Grosse bei sich herumsitzen, sprach aber die meiste Zeit mit dem Generalfeldzeugmeister Bruce, welcher auf seiner linken Seite saß. Währender Zeit, daß Ihro Hoheit ein Paar englische Tänze nach einander tanzten, kam die Tochter der verwitweten Zarin, und setzte sich wieder auf ihre vorige Stelle, neben der Kaiserin an, welche Ihro Hoheit in ihrer Abwesenheit bekleidet hatten; so bald aber der englische Tanz vorbei war, rief die Kaiserin schon wieder den Herzog zu sich, und mußte die Braut, die mitten unter dem Himmel der Kaiserin zur rechten Hand saß, aufstehen, Ihro Hoheit ihren Platz abreten ... . Nachdem forderte der Kammerjunker Balk die Prinzeßin auf zum Tanz, und tanzte polnisch mit ihr; die Damen standen gleich auf, wie sie anfing, und da sie gegen der Kaiserin über kam, und einen Reverenz machte, stunden Thro Hoheit gleichfalls auf, und blieben stehen, bis der Tanz zum Ende war." (Bergholz 1721/1785, 155-6)

31 "Bei diesen Worten kam der General Jagusinski ins Zimmer, mit welchem die Kaiserin einen englischen Tanz anfing, welcher aus 8 oder 9 Paaren bestand, und sehr lang war. Die Kaiserin und die Prinzeßin setzten sich nieder, wenn die Reihe nicht an ihnen war zu tanzen, um ein wenig wieder auszuruhen." Wedding of Major Matuskin of the Guard and a widow named "Jacobsowna" whose deceased husband had also been a Major of the Guard. (Bergholz 1721/1785, 175)

32 " $\mathrm{Da}$ wir nun so lange, wie die Braut bei uns gewesen, nicht hatten englisch und Contratänze tanzen dürfen. ..." (Bergholz 1722/1786, 424) 
The free dancing at other weddings witnessed by Bergholz was varied. At Major Matuskin's wedding held on 12 November 1721, there was not only an English dance, but also Polish dances, minuets and a group dance similar to what Bergholz knew as the German Kettentanz, or chain dance (Bergholz 1721/1785, 174-5). At the wedding ball for Prince Trubetskoi on 7 November 1721, the free dancing began with Polish dances. The minuets came afterwards, and they were followed by a group dance unfamiliar to Bergholz in which eight or nine couples participated. As in the case of the wedding ball for Prince Repnin, the free dancing closed with a Polish dance (Bergholz 1721/1785, 169-70). The free dancing that took place at all the other Russian wedding balls described by Bergholz followed the same principle of interspersing Polish dances with minuets and various group dances.

The Russian wedding ball invariably closed with another ceremonial dance, which Bergholz calls the Abschiedstanz, or farewell dance. This could immediately follow the last free dance or, at the Tsar's discretion, it could wait until more forced drinking took place. Only married people could participate in the farewell dance; unmarried people such as Bergholz and the Duke of Holstein would sometimes remain in the ballroom and continue to dance freely well into the next morning. If the bridal chamber were in another house, then the newlyweds would be accompanied there in a procession led by trumpeters and including all the wedding officials and the "wedding family" (Bergholz 1721/1785, 175 and 156). Once the bridal chamber was reached, more ceremonies would ensue. These consisted of sweets being offered to guests and ever more alcohol being forced upon the groom. Only intermittently would the bridal party leave the bedchamber and allow the newlyweds to rest.

At Prince Repnin's wedding, the farewell dance began shortly after eight oclock in the evening. Bergholz implies in the following passage that the Tsaritsa successfully managed to influence the timing of this component.

At eight oclock, the Tsaritsa walked to the Tsar, whom she caressed a lot, and after she had kissed his forehead a few times, he stood up, and with this, the usual farewell dance was danced as follows. Namely, they stood in exactly the same way as they had in the previously mentioned dances [the opening ceremonial dancing]. Only these things were different: first of all, instead of the three couples, they [the participating dancers] now consisted of five couples; secondly, the Marschall, holding his staff, danced at the head of the line and everybody else had to follow him; and thirdly, they immediately began to dance Polish [omitting the formal reverences of the opening ceremonial dancing]. During the dance, all of the Schaffer held wax candles in one hand and they used these to direct the people who were dancing towards the bridal chamber. However, since the groom did not live in the house where the wedding celebrations were being held, but in his father's house, both [the newlyweds] were brought to the coach and they were accompanied home by their wedding family. ${ }^{33}$

33 "Um 8 Uhr ging die Kaiserin zum Kaiser, welchen sie sehr carreßirte, und nachdem sie ihm einigemal den Vorkopf geküsset hatte, stand er auf, und es ward hiermit der gewöhnliche Abschiedstanz getanzet, welcher folgendermassen gehalten wurde. Nemlich, sie stunden eben so, wie in den vorher 
Among Bergholz's descriptions, the one Russian wedding ceremony which significantly differed from the normal pattern was that of Duke Karl Friedrich of Holstein to Princess Anna Petrovna, held on 21 May 1725. In an unusual atmosphere of decorum, there was no forced drinking and there was no communal party in the bridal chamber. The only dancing at this royal wedding was in the form of a staging of "human curiosities" which was evidently considered to have been charming, even if it seems distasteful to modern sensibilities. Two large cakes had been placed upon the bride's and groom's respective tables, and after a little while, the tops of the cakes were removed, allowing a dwarf to step out of each one. A male dwarf drank to the bride's health, and a female dwarf danced around her cake (Bergholz 1725/1788, 536).

\section{FOREIGN WEDDINGS IN RUSSIA}

The wedding ceremonies Bergholz observed among foreign residents of Russia were remarkably similar to those held among the Russians themselves. Similarities included the use of proxy relatives (though less numerous than at Russian weddings) and wedding officials (though more numerous than at Russian weddings) and the prevalence of drunkenness. The general format of the wedding ball was also the same, though individual details could vary. Bergholz was apparently told that wedding ceremonies observed in the foreign communities of Russia were in fact the models on which Russian wedding ceremonies were based.

The local merchants, for the most part, have exactly the same ceremonies at their weddings as do the foremost Russians, for it is maintained that the Russians got those [ceremonies] from them and that the merchants have now changed this and that so as not to be exactly the same as them. ${ }^{34}$

Since, as we have seen, the Russian traditions could at least in part be traced back to the beginning of the sixteenth century, one cannot accept these remarks uncritically. There definitely appears to have been cross-cultural borrowing but the origins of the traditions are not clear.

One of the distinctions of the foreign weddings Bergholz attended in Moscow and St. Petersburg was that marriage rites seem to have taken place not in church, but in the house where all the other wedding celebrations were held. This was the case for the wedding held in the Foreign Quarter of Moscow between the young Dutch merchant von Jewern and the daughter of the rich old

erwehnten Tänzen gestellet, nur dieses war der Unterscheid: erstlich, daß sie anstatt der drei Paaren, jetzt aus fünf Paaren bestunden; zweitens, daß der Marschall mit seinem Stab vorantanzte, welchem die andern alle folgen mußten; und drittens, daß sie gleich polnisch zu tanzen anfingen. Die sämmtlichen Schaffer haben während des Tanzes Wachskerzen in einer Hand, und pflegen damit diese tanzenden Personen nach dem Schlafzimmer der Braut zu begleiten; da aber der Bräutigam nicht im Hochzeitshause, sondern bei seinem Vater im Hause wohnete, so brachten sie beide nach dem Wagen, und sie wurden durch ihre Hochzeitsfamilie nach Hause begleitet." (Bergholz 1721/1785, 156)

34 "Die hiesigen Kaufleute haben meistens eben dieselben Ceremonien auf ihren Hochzeiten, wie die vornehmen Russen, denn man versichert, daß die Russen selbige von ihnen haben, und daß die Kaufleute vorsetzlich jetzt nur eins und das andere geändert hätten, um nicht darinn gänzlich ihnen gleich zu sein." (Bergholz 1722/1786, 421) 
merchant Meier. A Protestant preacher began the rite of marriage once all the guests had arrived (sometime after one oclock in the afternoon), and this ceremony was followed by dinner (Bergholz 1722/1786, 495). The same thing occurred the following year in St. Petersburg at the wedding of a Herr Schumacher to a young woman by the name of Belten (Bergholz 1723/1787, 235). A wedding which took place in Reval (now Tallin, Estonia) on 11 July 1723, between a local twenty-year-old baron by the name of Hastfer and a thirteen-year-old girl whom Bergholz calls Fräulein Baranoff, seems to have followed local, presumably Swedish, customs. As in the German weddings mentioned above, the marriage rite took place in the same house where the rest of the wedding celebrations were held (Bergholz 1723/1787, 284-5).

Bergholz does not mention a single marriage rite taking place in a Catholic or Protestant church, though he does elsewhere refer to the Catholic, Lutheran and Reformed churches in Moscow. ${ }^{35}$ There may have been simple reasons for the absence of a church rite in certain cases, such as in the case of von Jewern's wedding in Moscow mentioned above. Not only did this wedding conflict with a day set aside according to the Tsar's command for an assembly, but invitations had been issued surreptitiously in order to avoid overcrowding Mademoiselle Hopmann's living quarters, where the celebrations were to take place, with "Russian nobles and others" (Bergholz 1722/1786, 421). One might suspect that a church ceremony may have been avoided for the sake of keeping a low profile. Similar arguments cannot, however, be made for the foreign weddings held in St. Petersburg and Reval. Besides questioning why church ceremonies did not seem to have taken place in these cases, one may also question how it could be that Russian ceremonies, in their elaborate attention to customs surrounding the church rite, were based on these foreign ceremonies without even so much as a procession. One must conclude that at least the processional and religious aspects of the Petrine wedding ceremony were not indebted to the heritage of foreign merchants in Russia.

Some distinctions of foreign weddings observed by Bergholz were clearly related to the level of material wealth at the disposal of the hosts. For example, at a wedding held at the home of a Swedish general, ${ }^{36}$ there was no music and there was no dancing until the Duke of Holstein insisted that there be some.

Even though it was to be a quiet wedding with no music, and even though only three to four female Swedish prisoners were there, His Highness absolutely wanted to dance and would not be quieted until a musical ensemble, bad as it was, had been formed. ${ }^{37}$

35 For example: Bergholz, 1722/1786, 349 (10 January); 450 (26 March); 476 (22 April); 525 (23 August).

36 The general had probably been captured during the Great Northern War (1700-1709).

37 "Ob nun zwar dort eine stille Hochzeit ohne Musik hat sollen gehalten werden, auch nur drei bis vier schwedische gefangene Frauen da gewesen, so haben Ihro Hoheit doch absolument tanzen wollen, und nicht eher geruhet, als bis sie sich eine Musik, so schlecht sie auch gewesen, verschaffet haben." 
Other differences between Russian and foreign weddings in Russia can be attributed to differences in the perception of social hierarchy. For example, at the Russian ceremonies, no exception seems to have been made to the rule that only married people could participate in the Abschiedstanz. Yet at the aforementioned wedding of Herr Schumacher to Jungfer Belten on 30 April 1723, the still single Duke of Holstein placed himself among those dancing to the bridal chamber (Bergholz 1723/1787, 237).

In his entry for 1 March 1722, Bergholz describes in significant detail the wedding celebration held for Demoiselle Hopman and Kaufmann Lübsch in Moscow. There appears to have been the same assortment of proxy relatives and wedding officials as there were at Russian weddings, and the quantity of alcohol consumed was also comparable to that at Russian weddings. Bergholz's unsuccessful pleas to be excused from the ritual drinking supervised by the Marschall of the ceremony, Kaufmann Meier, prove that a strong element of coercion was by no means confined to Russian celebrations (Bergholz 1722/1786, 421). The wedding ball for the Hopman-Lübsch wedding was also very similar in substance to the wedding ball practised at Russian weddings. Bergholz notes the main differences as follows.

I have observed that the Marschall at burgher weddings ${ }^{38}$ has much more freedom than the Marschall at Russian weddings. First of all, he can make rules according to his fancy. For example, after the ceremonial dance was over, [today's] Marschall announced that everybody was now free to dance, but that one minuet should be danced for every three Polish dances, and that whoever should break this rule would immediately have to drink a penalty glass. According to what he told me, the Marschall did this on the one hand so that the ladies, who were quite numerous, would be able to dance more often, since three couples always danced the Polish dance together but only one couple could dance the minuet at a time; but on the other hand, he did it so that, during the dance, a little more would be drunk. Furthermore, it is completely up to the Marschall when the bride is to be danced to bed and when she is to be awoken again; similarly, it is at his discretion to say when the whole ball and amusement should come to an end. ${ }^{39}$

An obvious explanation for the heightened freedom of the Marschall at "burgher weddings" might be that the Tsar was rarely present at the foreign wed-

38 By "Bürger-Hochzeiten," Bergholz was likely referring to weddings held by the merchant-class residents of the Foreign Quarter in Moscow.

39 "[Zum dritten] habe ich observiret, daß der Marschall auf den Bürger-Hochzeiten viel mehr Freiheit hat, als der Marschall bei den Russen. Erstlich kann er Gesetze machen wie er will, unter andern kündigte dieser an, nachdem der Ceremoniel-Tanz vorbei war, daß ein jeder nun Freiheit hätte zu tanzen, dabei aber in acht zu nehmen, daß man nur eine Menuette dürfte unter der Zeit machen, da drei polnische Tänze getanzet würden, und wer dagegen verbreche, der sollte ein Strafglas sobald austrinken; dieses that der Marschall, wie er mir sagte, eines theils aus der Absicht, daß die Damen, welche ziemlich zahlreich waren, um so viel öfter zum Tanz kämen, indem den polnischen Tanz allezeit drei Paar, den Menuettanz aber nur ein Paar zugleich tanzen; andern theils thäte er es auch, damit unterm Tanz noch ein Gläschen getrunken würde. Zum andern, stehet es bei dem Marschall einzig und allein, wenn er die Braut zu Bette tanzen, und wenn er sie wieder aufwecken will; imgleichen, wenn er allen Tanz und alle Lustbarkeit aufhören lassen will." (Bergholz 1722/1786, 422) 
dings described in the Tagebuch and that when he did attend, he acted more as a compliant guest than as the general director of everybody present, including the designated Marschall. ${ }^{40}$

Later in the same entry, Bergholz describes the dancing that took place at this wedding in somewhat more detail. He writes that the free dancing lasted until two oclock in the morning. The ensuing farewell dance was no different than the one occurring at Russian weddings except that the groom's Schaffer and the Vorschneider were not allowed to enter into the bridal chamber (Bergholz $1722 / 1786,423)$. While the married people were involved with drinking in the bridal chamber, the young people, including Bergholz, danced around merrily.

While the bride had been with us, we had not been able to dance English and Contratänze, so we now began to dance these dances with all our might, for the old people were in the bridal chamber and had to drink worthily. After they had been in the chamber for around an hour, they came out, and the Marschall brought a large bowl of sweets, carried by and delivered by the bride's Schaffer, to each of the two bridesmaids as a present from the bride. Then the dance was resumed and it apparently lasted until around five oclock in the morning [one hour after Bergholz had left the celebration], at which time the Marschall, Schaffer and other men who were present, according to custom, had to wake up the groom again, and the groom was compelled to get up again, to open the door to them, and to drink with them for as long as they wanted. ...1

The only wedding ball described by Bergholz that significantly differed from the norm was the one held in Reval in July, 1723. Although, to be sure, there were many elements in common with the weddings held among Russian aristocrats and among the foreign residents of St. Petersburg and Moscow, there were also some differences. Since Reval had only been captured (or reclaimed) from Sweden thirteen years before, one may presume that the distinct customs observed at this wedding were, in fact, not Russian. The dancing began at eight o'clock in the evening, and it seems to have begun with familiar, though slightly modified, elements. The beginning of the wedding ball is described as follows.

At the front, two Marschälle were dancing (of whom there are usually four at a wedding, but today were six), then came the bride and groom, then

40 See, for example, Bergholz 1723/1787, 235-8 and Bergholz 1724/1788, 497.

41 " $\mathrm{Da}$ wir nun so lange, wie die Braut bei uns gewesen, nicht hatten englisch und Contratänze tanzen dürfen, so fingen wir selbige nun mit voller Macht an, und sprungen währender Zeit, da die Alten in der Brautkammer waren, und brav trinken mußten, lustig herum. Nachdem sie nun ohngefähr waren eine Stunde in der Kammer gewesen, kamen sie heraus, und es brachte der Marschall den beiden Brautjungfern zum Present von der Braut jeder eine grosse Schüssel mit Confitüren, welche die BrautSchaffer tragen, und ihnen überreichen mußten; worauf der Tanz continuiret wurde, und man sagte mir, daß er bis gegen 5 Uhr währen sollte, um welche Zeit der Marschall mit den Schaffern, und übrigen anwesenden Mannsleuten, der Gewohnheit nach, den Bräutigam wieder aufwecken müssen, der denn gezwungen ist, wieder aufzustehen, ihnen die Thür aufzumachen, und mit ihnen, so lange sie wollen, zu trinken...." (Bergholz 1722/1786, 424) 
$\mathrm{H}$ [is] H[ighness] with Countess Welling, and then the eldest Prince of Hessen with the Countess Wachtmeistern. ${ }^{42}$

Since Bergholz did not trouble himself to name the dance(s), since the dancing was clearly processional and rank-asserting in nature, and since it was set apart from the following dances in Bergholz's description, one can safely conclude that this part of the wedding ball corresponded to the opening ceremonial dancing found at all the wedding balls attended by Bergholz.

After the first dance of the Reval wedding ball was finished, dances open to everybody ensued; these were Polish dances, minuets and English dances. The first pair to dance consisted of the bride and the Duke of Holstein, who acted as proxy father-of-the-bride. The free dancing lasted well into the evening; it was followed by a dance that was hitherto unknown to Bergholz and that closed this wedding ball. Bergholz not only provides an uncharacteristically detailed description of the appearance of the dance, but he also clearly shows how the Tsar took on the role of student rather than commander.

At around eleven oclock, the closing ceremonial dances began, and these were completely different from the Muscovite [i.e., of the Foreign Quarter] and Russian ones. First, all the young men danced the Polish two-by-two behind the groom, in front of whom two Marschälle danced. Then they joined [hands] and formed a circle, and the groom entered the circle and took one of the young men with him. After the groom swung around with him a little and kissed him, he then seized another one, and this pattern continued all the way round the circle. After this, they lifted the groom high up in their hands, and he had to drink down three glasses of wine and then throw [the glasses] onto the floor. At this point, [the young men] first jumped around a little with him and then let him down onto the ground. At this point, [the groom] was caught by new men, and they danced with him after the same fashion. As the Emperor had now watched all of these ceremonies attentively, he himself now danced this dance with the groom and joined in with everything. After the groom had finished dancing as described, all the young women and then all the older women danced with the bride in exactly the same manner. The only difference was that the bride was not lifted into the air as the groom had been and she did not have to drink. Also, the two Marschälle (who were leading this dance, as well) only kissed the bride's hand, although they danced with her in the circle exactly as the young women and older women did. During this dance, drums and trumpets played together with the music, and when the dancing was over, the bride and groom were wished good luck once again. ${ }^{43}$

42 "Gegen 8 Uhr ging der Tanz an, und geschahe folgendermassen. Voran tanzten zwei Marschälle, (deren gemeiniglich vier auf einer Hochzeit sind, heute aber 6 waren,) nachher kamen Braut- und Bräutigam, ferner I.H. mit der Gräfin Welling, und hierauf der älteste Prinz von Hessen mit der Gräfin Wachtmeistern." (Bergholz 1723/1787, 284)

43 "Gegen 11 Uhr gingen die letzten Ceremonientänze an, welche ganz anders wie die moscowitischen und rußischen sind. Denn erst tanzten alle Junggesellen paarweise auf polnisch hinter dem Bräutigam her, vor welchem zwei Marschälle hertanzten; nachher faßten sie sich an, und formirten einen Ring, in welchen der Bräutigam hineinging, einen der Junggesellen zu sich nahm, und nachdem er sich mit ihm herumgeschwäket, und ihn geküsset hatte, einen andern ergriff, welches so lange währete, bis die Reihe herum war. Nachdem hoben sie den Bräutigam auf den Händen in die Höhe, und er mußte 
The ceremonial dance described here, in its circular enclosure of the newlyweds, resembles a traditional Polish dance encircling the bride (Cohen 1998, s.v. "Poland: Traditional and Social Dance" by Grażyna Dąbrowska).

\section{Closing Remarks}

Although the Russian wedding ceremony under the reign of Peter I was in most respects a festive occasion, it in reality included a fair amount of coarseness and even cruelty. Guests laughed at the Tsar's practical jokes, but various degrees of real suffering were involved. The forced drunkenness is the most obvious example of this aspect of the wedding ceremony, but it is not the only one. On one occasion, Peter literally force-fed the bride's real father, making him swallow bowlful after bowlful of Gelét4 (Bergholz 1721/1785, 169). A favourite trick of the Tsar was to force old men to dance for protracted periods with young ladies. For the sake of Peter's amusement, these men were forcibly made so exhausted that they were barely able to stand on their feet (Bergholz 1721/1785, 170-1 and 175; Bergholz 1722/1786, 464). Once, at a wedding held at the beginning of March, the Tsar felt that the temperature in the ballroom was too warm. When he was not able to open a window in the usual manner, he used a hatchet to remove it from the wall altogether, letting in a cold wind which, according to Bergholz, greatly inconvenienced many of the ladies (Bergholz 1722/1786, 462463). Failure to comply with the traditions of the wedding ball could also lead to unpleasant consequences. When General Iaguzhinsky's first wife had agreed at the last minute to fill the role of "bride's sister," but had refused to dance when she was supposed to do so, the General raged at her until the groom's real sister offered to take her place (Bergholz 1722/1786, 472). For having argued with her husband, the Tsar ordered that Iaguzhinsky's wife be banished to a convent; this order was carried out within a month's time (Bergholz 1722/1786, 491).

A different kind of cruelty loosely connected to our topic was evidenced by the display of Russian slave women to the Holstein suite by a Dutch merchant named Tamsen. On 13 February 1722, Tamsen invited the Duke of Holstein's entire retinue to view his linen factory. As part of the entertainment, the merchant had one of his slave women play the balalaika while two others performed what was supposedly a traditional Russian wedding dance. One woman played the bride, and the other played the groom. Together, they acted out seduction in their dance. When the inevitable became imminent, a boy of nine or ten years

drei Gläser Wein austrinken, und sie alsdenn auf die Erde werfen. Nun sprangen sie noch eine Weile mit ihm herum, und liessen ihn hernach wieder herunter. Hierauf empfingen ihn lauter Männer, und tanzten auf dieselbige Weise mit ihm. Als nun der Kaiser alle diese Ceremonien mit Aufmerksamkeit angesehen hatte, tanzte er selbst diesen Tanz mit dem Bräutigam, und machte alles mit. Nachdem der Bräutigam erwehntermassen getanzet hatte, tanzten alle Jungfern und alsdenn alle Frauen auf eben diese Weise mit der Braut; und der Unterscheid hierbei war nur, daß die Braut nicht wie der Bräutigam aufgehoben ward, und trinken mußte; es küsseten auch die beiden Marschälle (welche auch bei diesem Tanz voran tanzten,) der Braut nur die Hand, tanzten aber mit ihr eben so wie die Jungfern und Frauen im Kreise herum. Bei diesem Tanz liessen sich Paucken und Trompeten mit der Musik zusammen hören, und als die Tänze vorbei waren, so wurde Braut und Bräutigam nochmals Glück gewünschet." (Bergholz $1723 / 1787,284-5)$

44 Bergholz was probably referring to kholodets, a jellied meat dish. 
took over the role of groom and acted out the culmination atop the blindfolded bride (Bergholz 1722/1786, 395-6). In this case, the performers were fully clothed, but at an actual wedding ceremony hosted by Tamsen for his housekeeper, the merchant had one of his crews of linen workers wrestle in the nude for the entertainment of his guests (Bergholz 1722/1786, 498). The apparent insensitivity of these occurrences might be somewhat mitigated by the fact that, according to Bergholz, many of the foremost Russians enjoyed not only watching this kind of game, but also participating in it (Bergholz 1722/1786, 498).

Although coarseness and cruelty played a role at weddings in Petrine Russia, we have also seen that the rituals encompassing music-making and dancing were quite inventive and sophisticated. We have been able to determine a definite but flexible procedure, consisting of ceremonial and free dances, and bearing some resemblance to the formal procedures for the King's Grand Ball described by Pierre Rameau in 1725 . The dance types encountered at the Russian wedding ball included Polish dances, minuets, English dances and other group dances. Polish dances, occurring in all three segments of the Petrine wedding ball, seem to have been the principal kinetic fare of the celebration. Relatively minor discrepancies notwithstanding, the foreign weddings recorded in Bergholz's diary seem to have been of the same breed as the Russian weddings.

We have shown that the ceremonial dancing at the Russian wedding ball under Peter I was defined not by dance type, but by when the dancing occurred and by the identity of the dancers. The opening ceremonial dancing was performed by six predetermined pairings of wedding officials and surrogate wedding relatives, and the closing ceremonial dancing was performed by all married guests. On one level, the predetermined pairings of the opening ceremonial dances resemble the predetermined succession of dancers at the formal ball described by Pierre Rameau, though the ordering at the French ball was determined not by temporarily assigned roles, but by social rank. On another level, the predetermined pairings of the Russian ceremonial dances amounted to a carefully controlled subversion of normal social hierarchy.

We have also seen how dancing at Russian weddings under Peter the Great functioned not only as entertainment for the guests, but also sometimes as entertainment for the Tsar at the expense of the guests. Perhaps most significantly, the predetermined pairings of wedding officials and surrogate relatives on the dance floor gave tangible form to an otherwise intangible amusement. If it were not for the ceremonial dancing, then much of the fun of being a wedding official or proxy relative would have been lost. In fact, like so many of Peter I's pastimes, the Russian wedding ceremony provided a means with which usual rank and protocol could be confounded, though always, of course, under the direct rule of the Tsar.

\section{REFERENCES}

Adelung, Johann Christoph. 1798. Grammatisch-kritisches Wörterbuch der Hochdeutschen Mundart mit beständiger Vergleichung der übrigen Mundarten, besonders aber der Oberdeutschen [Grammatical-Critical Dictionary of the 
High-German Dialect with Constant Comparison with the Other Dialects, Especially to the Upper German Dialect], $2^{\text {nd }}$ ed. Leipzig: Breitkopf und Härtel. Reprint ed. 1970. Hildesheim and New York: Georg Olms Verlag. S.v. "Der Hochzeitsvater," "Der Marschall," "Der Schaffer," "Der Schaffner," "Vorschneiden" and "Vorschneider."

Bergholz, Friedrich Wilhelm von. 1785-88. "Tagebuch" [Diary]. In Magazin für die neue Historie und Geographie [Journal for Modern History and Geography], vols. 19-22, ed. Anton Friedrich Büsching, 4-202, 331-592, 178360 and 425-553. Halle: sel. Johann Jacob Curts Wittwe.

Cohen, Selma Jeanne, founding ed. 1998. International Encyclopedia of Dance. New York and Oxford: Oxford University Press. S.v. "Polonaise" by Susan Au and s.v. "Poland: Traditional and Social Dance" by Grażyna Dąbrowska.

Findeizen, Nikolai Fedorovich. 1928. Ocherki po Istorii Muzyki v Rossii s Drevneishikh Vremen do Kontsa XVIII veka [Essays on the History of Music in Russia from Ancient Times until the End of the Eighteenth Century]. Moscow and Leningrad: Muzsektor, Gosudarstvennoe Izdatel'stvo.

Kaiser, Daniel H. 1987. "Symbol and Ritual in the Marriages of Ivan IV." Russian History 14 (1987).

Kolesov, V. V., ed. 1991. Domostroi [Household Management]. Moscow: Khudozhestvennaia literatura.

Martin, Russell E. 2004. “Choreographing the 'Tsar's Happy Occasion': Tradition, Change, and Dynastic Legitimacy in the Weddings of Tsar Mikhail Romanov." Slavic Review 63, no. 4 (Winter): 794-817.

Meyer-Baer, Kathi. 1970. Music of the Spheres and the Dance of Death: Studies in Musical Iconology. Princeton: Princeton University Press.

Pokhlebkin, William. 1992. A History of Vodka. Trans. Renfrey Clarke. London and New York: Verso.

Pouncy, Carolyn Johnston, ed. 1994. The Domostroi: Rules for Russian Households in the Time of Ivan the Terrible. Ithaca and London: Cornell University Press.

Rameau, Pierre. 1725. Le Maître d̀ danser [The Dancing Master]. Paris. Translated by Cyril Beaumont. 1931. London. Reprint ed. 1970. Brooklyn, NY: Dance Horizons.

Sander, Elizabeth. 2002. "Social Dancing in Russia at the End of the Petrine Era: Friedrich Wilhelm von Bergholz's Tagebuch, 1721-1725." Ph.D. diss., University of Western Ontario.

Semenova, Lidiia Nikolaevna. 1982. Ocherki Istorii Byta i Kul'turnoi Zhizni Rossii (Pervaia polovina XVIII v.) [Essays on the History of Daily Life and on the Cultural History of Russia (First half of the eighteenth century)]. Leningrad: Nauka.

\section{Abstract}

Dance and related rituals as practised at aristocratic wedding ceremonies in Russia at the end of the reign of Peter I ("the Great," 1672-1725) are examined in this article. The central source employed in this research is a diary written in 
Russia by the Holstein nobleman Friedrich Wilhelm von Bergholz (1699-1765) between 1721 and 1725. Dancing on the first day of the aristocratic Petrine wedding ceremony was evidently governed by a stable formal plan consisting of formal reverences, ceremonial dancing and free dancing. Minuets, as well as dances identified as Polish and English, were danced.

\section{RÉSUMÉ}

Nous étudions dans cet article la danse et les rituels colatéraux tels qu'ils ont été pratiqués lors de cérémonies de mariages aristocratiques en Russie à la fin du règne de Pierre $1^{\text {er }}$ (dit "le Grand », 1672-1725). La principale source utilisée pour cette recherche est un journal écrit par le noble Holstein Friedrich Wilhelm von Bergholz (1699-1765) entre 1721 and 1725 lors de son séjour en Russie. Les danses utilisées à loccasion de ces cérémonies répondaient naturellement à un plan formel consistant en révérences, cérémonial de danses et danses libres. Les menuets, ainsi que d'autres danses identifiées comme Polonaise et Anglaise, étaient également en faveur. 